\title{
Bird Strike Analysis on 19 Passenger Aircraft Windshield with Different Thickness and Impact Velocity
}

\author{
Budi Aji Warsiyanto ${ }^{* 1}$, Sahril Afandi Sitompul ${ }^{2}$, Endah Yuniarti ${ }^{3}$, \\ Rizky Fitriansyah ${ }^{4}$, Agus Bayu ${ }^{5}$ \\ 1,2,3 Faculty of Aerospace Technology, The Aerospace Air Marshal Suryadarma University, Indonesia \\ ${ }^{4,5} \mathrm{National}$ Institute of Aeronautics and Space, Indonesia \\ ${ }^{*}$ Corresponding Author: budiajiwarsiyanto@gmail.com
}

\begin{abstract}
A Windshield is a component that must be tested to comply with the certification requirements in the bird strike phenomenon based on Civil Aviation Safety Regulations (CASR) subpart 23.775. The purpose of this study is to obtain the thickness of 19 passenger aircraft windshield that meets the certification requirements and determine the dynamic response of the windshield to impact velocity variations. The finite element is used to simulate bird strike phenomena. The elastic-plastic polymethyl methacrylate (PMMA) material with the maximum principal strain failure criterion is used to model the dynamic response of the windshield. Numerical modeling is validated, both with analytical and experimental results which are then used to investigate the effect of variations in windshield thickness and impact velocity. The results obtained that with a thickness of $9 \mathrm{~mm}$, the windshield is able to withstand bird strikes based on cases that have been determined by the regulation. In addition, the impact velocity that causes the dynamic response of the windshield in the elastic, plastic deformation, and the greatest failure is the velocity of $87.5 \mathrm{~ms}^{-1}$ (cruising phase). The uppermost of the windshield (fixed) is the weakest part due to the stress concentration.
\end{abstract}

Keywords: Bird strike, 19 passenger commuter aircraft windshield, Dynamic response, Civil Aviation Safety Regulation (CASR), Finite element method

\begin{abstract}
Abstrak -Windshield merupakan komponen yang harus diuji untuk memenuhi persyaratan sertifikasi pada kasus bird strike berdasarkan Civil Aviation Safety Regulation (CASR) subbagian 23.775. Tujuan tugas akhir ini adalah untuk memperoleh ketebalan windshield pesawat 19 penumpang yang memenuhi persyaratan sertifikasi dan mengetahui respon dinamik windshield terhadap variasi kecepatan tumbukan. Elemen hingga digunakan untuk mensimulasikan fenomena bird strike. Material polimetil metakrilat (PMMA) elastis-plastis dengan kriteria kegagalan regangan utama digunakan untuk memodelkan respon tumbukan dari windshield. Pemodelan numerik divalidasi, baik dengan hasil analitik maupun eksperimen yang selanjutnya digunakan untuk menginvestigasi pengaruh dari variasi ketebalan windshield dan kecepatan tumbukan (kecepatan, sudut tumbukan, dan massa burung). Diperoleh hasil bahwa dengan ketebalan $9 \mathrm{~mm}$, windshield mampu menahan bird strike berdasarkan kasus yang telah ditentukan oleh regulasi. Selain itu, kecepatan tumbukan yang menyebabkan respon dinamik windshield berupa deformasi elastis, plastis, dan kegagalan paling besar adalah kecepatan $87.5 \mathrm{~ms}^{-1}$ (fase cruising). Ujung atas windshield (di-fixed) menjadi bagian yang paling lemah karena terjadi konsentrasi tegangan.
\end{abstract}

Kata kunci: Bird strike, Windshield pesawat komuter 19 penumpang, Respon dinamik, Civil Aviation Safety Regulation (CASR), Metode elemen hingga.

\section{INTRODUCTION}

Commuter flights will still be a mainstay of Indonesia to open isolation in remote areas, both in the mountains and small islands. This is due to the large number of remote areas in Indonesia that have very short aircraft runways. In addition to this, the commuter aircraft used to serve pioneer flights are aged over 20 years [1]. Based on CASR part 23, the commuter category is limited to propeller-driven, multiengine airplanes that have a seating configuration, excluding pilot seats, of 19 or less, and a 
maximum certificated takeoff weight of 19,000 pounds or less [2].

Currently, the process of designing a commuter aircraft has achieved the testing phase of its components. The requirements for the test refer to the Civil Aviation Safety Regulation (CASR) part 23 issued by the Ministry of Transportation of the Republic of Indonesia. One of the tests carried out to obtain certification is the strength of the structure and components of the aircraft when it receives loads due to bird strikes. Based on CASR subpart 23.775, windshield panes directly in front of the pilots in the normal conduct of their duties, and the supporting structures for these panes, must withstand, without penetration, the impact of a two-pound bird when the velocity of the airplane (relative to the bird along the airplane's flight path) is equal to the airplane's maximum approach flap speed [2].

Based on the Federal Aviation Administration (FAA) data, from 2015 to 2019 there has been a bird strike phenomenon of more than 60,663 times. Bird strikes often occur at altitudes of less than 3,000 feet (914.4 meters) with a percentage of $95 \%$ [3]. Therefore, take-off, approach, and landing become critical flight phases in the phenomenon of a bird strike.

Components of fixed-wing aircraft with the potential to sustain bird strikes are shown in Fig. 1. However, in helicopters, components that have the potential to sustain bird strikes include windshield, fuselage panels, and rotor blades. Although aircraft components also have the potential to sustain attacks from other objects or Foreign Object Damage (FOD), $90 \%$ of damage is caused by bird strikes [4].

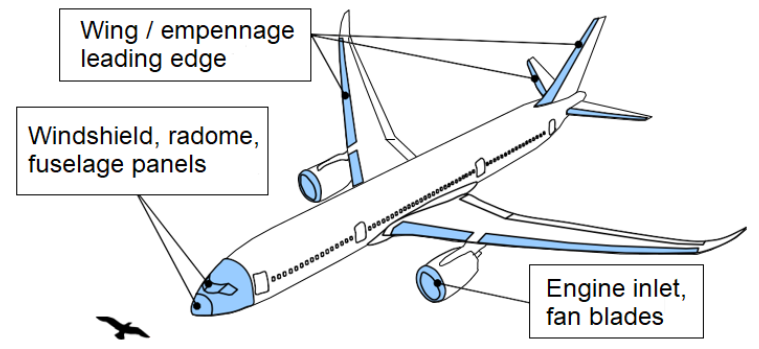

Figure 1. Components of an aircraft that has the potential to experience bird strike [5]
Experiments are the best method to analyze bird strikes realistically. However, this method is less effective (cannot give repeatable results due to differences in bird species) and less efficient (requires time and cost in the target or plate making process). In 1970, a more effective and efficient method was found, namely numerical software (finite element) application [6]. Nevertheless, experiments are still needed to validate numerical methods.

Several researchers, such as Zhu et al. [7] have investigated windshield responses to bird strikes using experimental and numerical methods, Zhufeng et al. [8], Wang et al [9], and Dar et al. [10] simulate the failure of the windshield with polymethyl methacrylate (PMMA) material against bird strike. Yuniarti and Sitompul [11] analyzes the effect of a cylindrical and hemisphericalcylinder bird model using the lagrangian method.

In this study, a bird strike simulation was carried out to determine the dynamic response of the windshield based on variations in the impact velocity. Simulations are carried out using Abaqus finite element software. Simulations are carried out on the impact velocity variations to test the energy that can be absorbed by the windshield, both before and after failure.

\section{NUMERICAL MODELING}

\subsection{Windshield Material Model}

The windshield considered in this study is homogeneous and use PMMAbased aviation organic glass. The material properties of the windshield used in the analysis are given in Table 1 . The elastoplastic material model along with the maximum principal strain failure criterion was defined to predict damage and failure of the windshield. The maximum principal strain criterion implies that if the maximum tensile principal strain exceeds the prescribed limits, then the material will instantaneously fail. Failure is predicted when either of the principal strain $\varepsilon_{1}$ or $\varepsilon_{2}$, resulting from the principal stresses $\sigma_{1}$ or $\sigma_{2}$, equals or exceeds the maximum strain corresponding to the yield strength $\sigma_{y}$ of the 
material in uniaxial tension or compression. For yielding in tension the minimum principle strain $\varepsilon_{1}$ would equal the yield strain in uniaxial tension. If the strain is expressed in terms of stress, then

Table 1. Material properties of windshield [10]

\begin{tabular}{cccccc}
\hline $\begin{array}{c}\text { Density } \\
\left(\mathbf{k g} \cdot \mathbf{m}^{-3}\right)\end{array}$ & $\begin{array}{c}\text { Elastic modulus } \\
(\mathrm{GPa})\end{array}$ & $\begin{array}{c}\text { Poisson's } \\
\text { ratio }\end{array}$ & $\begin{array}{c}\text { Yield strength } \\
(\mathrm{MPa})\end{array}$ & $\begin{array}{c}\text { Ultimate strength } \\
(\mathrm{MPa})\end{array}$ & $\begin{array}{c}\text { Failure } \\
\text { strain }\end{array}$ \\
\hline 1186 & 3.2 & 0.4 & 68 & 78 & 0.067 \\
\hline
\end{tabular}

Table 2. Material properties of bird [12]

\begin{tabular}{ccccc}
\hline $\begin{array}{c}\text { Density } \\
\left(\mathrm{kg} . \mathrm{m}^{-3}\right)\end{array}$ & $\begin{array}{c}\text { Shear modulus } \\
(\mathrm{MPa})\end{array}$ & Elastic strain & $\begin{array}{c}\text { Yield strength } \\
(\mathrm{MPa})\end{array}$ & $\begin{array}{c}\text { Hydrostatic stress } \\
(\mathrm{MPa})\end{array}$ \\
\hline 938 & 10 & 0.01 & 0.1 & 2.75 \\
\hline
\end{tabular}

$$
\begin{gathered}
\varepsilon_{1}=\frac{\sigma_{1}}{E}-\frac{v}{E}\left(\sigma_{2}+\sigma_{3}\right), \\
\sigma_{1}-v\left(\sigma_{2}+\sigma_{3}\right) \leq \sigma_{y}, \\
\varepsilon_{\text {fail }}=\varepsilon_{\text {total }}-\frac{\sigma_{\text {total }}}{E} \sigma>\sigma_{y} .
\end{gathered}
$$

\subsection{Bird Material Model}

The actual bird is a combination of flesh, blood, and bones, and it is difficult to implement in the numerical model. The bird is mostly composed of water. It behaves like a soft body and acts as a fluid. Water like a hydrodynamic response by using the Tabular equation of state (EOS). The Tabular EOS correlates the material strength and pressure to the density ratio. The Tabular equation of state is given in the form [12]:

$$
P_{H}=f_{1}\left(\varepsilon_{V}\right)+\rho_{0} f_{2}\left(\varepsilon_{V}\right) E_{m}
$$

where $f_{1}\left(\varepsilon_{V}\right)$ and $f_{2}\left(\varepsilon_{V}\right)$ are functions of the logarithmic volumetric strain $\varepsilon_{V}$ only, with $\varepsilon_{V}=\ln \left(\rho_{0} / \rho\right)$, and $E_{m}$ is the internal energy per unit mass. The internal energy contribution to the pressure is usually neglected when dealing with the hydrodynamic region of impact. Therefore, $f_{2}\left(\varepsilon_{V}\right)=0$ and $P_{H}=f_{1}\left(\varepsilon_{V}\right)$. The Tabular EOS representation of the curves in Fig. 2 requires only to take the natural logarithm of the density ratio $\rho_{0} / \rho$. The material properties of the bird are given in Table 2.

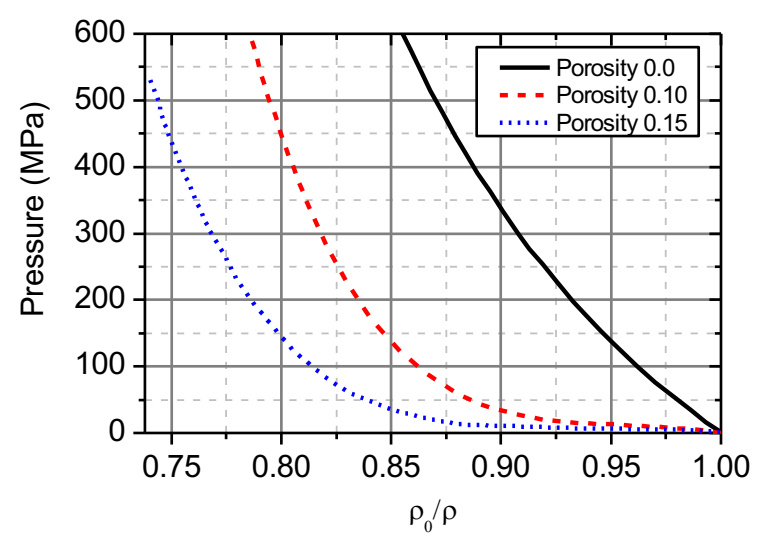

Figure 2. Hugoniot curves of water-like homogenized bird materials [12]

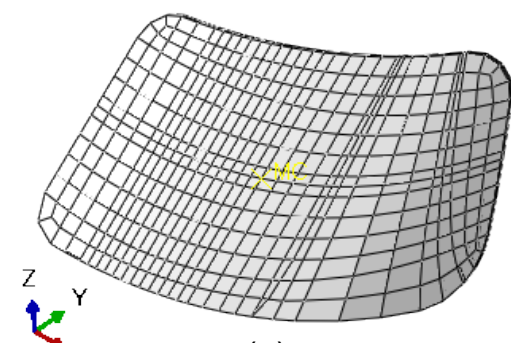

(a)

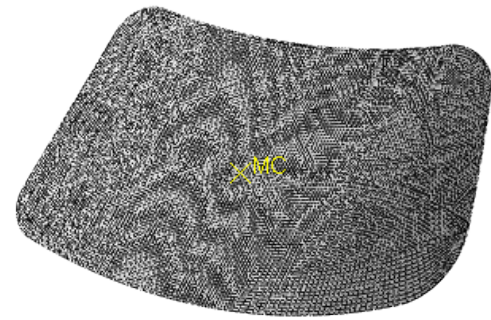

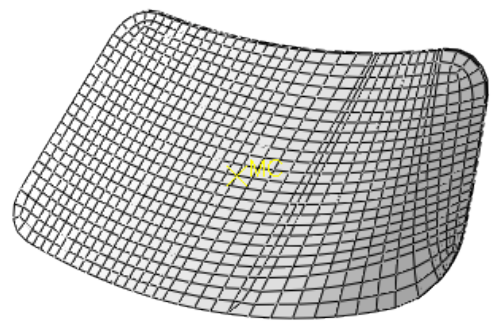

(b)

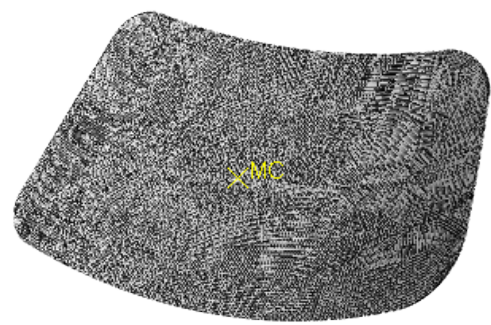

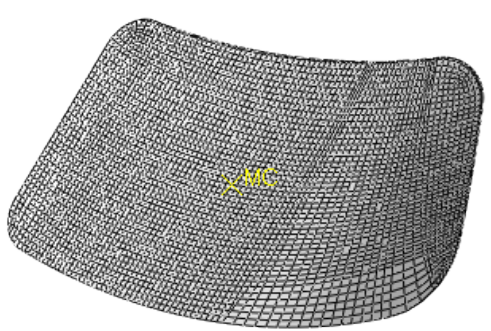

(c)

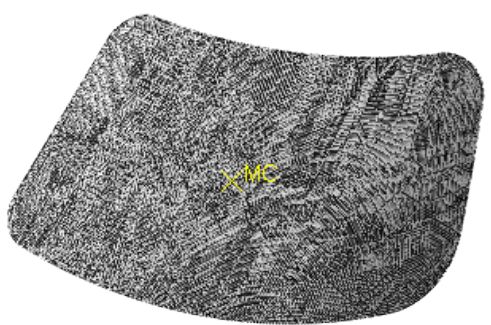


(d) (f)

Figure 3. Different of mesh size per element on the windshield model: (a) 50, (b) 30, (c) 15, (d) 8 , (e) 6 , and (f) $5 \mathrm{~mm}$

\subsection{Validation of Numerical Model \\ 2.3.1 Model for Windshield}

To validate the numerical model for the windshield is carried out a study of mesh convergence. The differences in mesh size per element for the windshield model are shown in Fig. 3. The effect of differences in mesh size is considered based on maximum displacement at the yellow point "MC" on the windshield that the results are shown in Fig. 4. As a result, mesh sizes per element 15-5 $\mathrm{mm}$ have convergent values. Therefore, in this study, a variation of the mesh size 15-5 $\mathrm{mm}$ on the windshield was used.

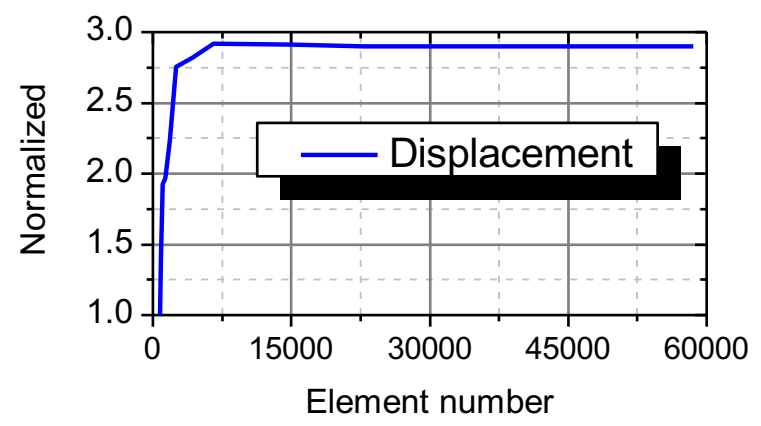

Figure 4. Mesh convergence study

\subsubsection{EOS for Bird}

To validate the Tabular EOS, the Hugoniot and stagnation pressures were compared with theoretically obtained pressure values and Wilbeck [13] experimental results. For theoretical calculations, one-dimensional Hugoniot analysis was carried out in which bird impact is characterized in two stages. The first stage is initial shock called Hugoniot pressure which gives the maximum possible value of pressure during impact, and the other stage is steady-state flow called stagnation pressure in which pressure stabilizes with time. The Hugoniot and stagnation pressure is given in the form:

$$
\begin{gathered}
P_{H}=P_{2}-P_{1}=\rho u_{s} u_{i} \\
P_{S}=\frac{1}{2} \rho v_{i}^{2}
\end{gathered}
$$

The bird is modeled as a cylinder with a length of $212 \mathrm{~mm}$ and a diameter of 108 $\mathrm{mm}$. For the steel plate, it is modeled as a square with a length of $1000 \mathrm{~mm}$ which is supported on each side [12]. At this stage, the impact velocity is varied with a value of 100,200 , and $300 \mathrm{~ms}^{-1}$. Simulation results are shown in the Hugoniot and stagnation pressure that is compared to the analytical results in Fig. 5 and $\mathbf{6}$, as well as Tables $\mathbf{3}$ and 4.

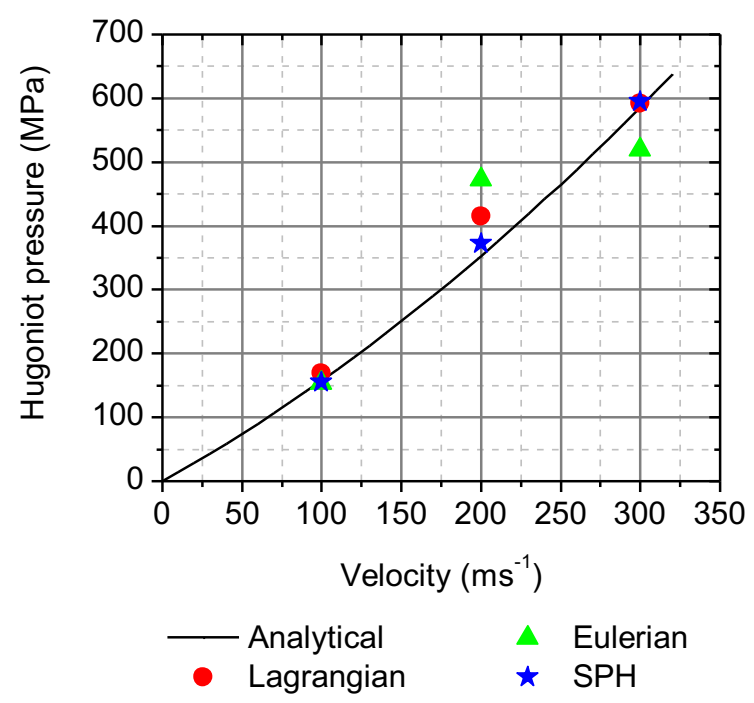

Figure 5. Comparison between the analytical and numerical methods of Hugoniot pressure

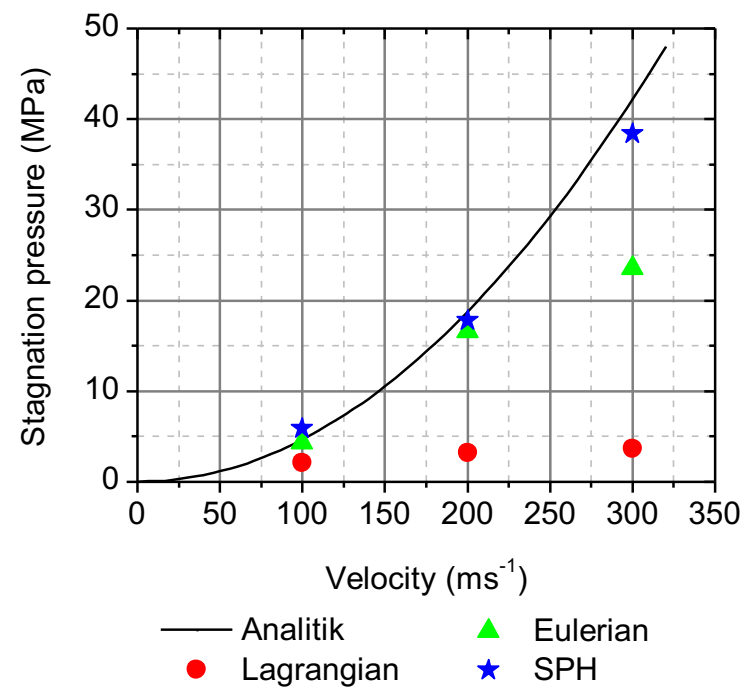

Figure 6. Comparison between the analytical and numerical methods of stagnation pressure 
Based on the results in Fig. 5 and $\mathbf{6}$, as well as Tables 3 and $\mathbf{4}$, it was found that the SPH method has the smallest error value from the other methods. For Hugoniot pressure, the SPH method has an average error value of $2.74 \%$ for each impact velocity, while stagnation pressure has an average error value of $13.01 \%$. Therefore, in this study, a bird with the SPH method was used.

Table 3. Comparison between the analytical and numerical methods of Hugoniot pressure

\begin{tabular}{cccccccc}
\hline \multirow{2}{*}{$\begin{array}{c}\text { Velocity } \\
\left(\mathbf{m s}^{-1}\right)\end{array}$} & \multirow{2}{*}{ Analytic } & \multicolumn{2}{c}{ Lagrangian } & \multicolumn{2}{c}{ Eulerian } & \multicolumn{2}{c}{ SPH } \\
\cline { 2 - 8 } & & Value & Error (\%) & Value & Error (\%) & Value & Error (\%) \\
\hline 100 & 157.95 & 169.07 & 7.04 & 153.65 & -2.72 & 155.07 & -1.82 \\
\hline 200 & 353.42 & 414.45 & 17.27 & 472.76 & 33.77 & 371.50 & 5.11 \\
\hline 300 & 586.41 & 592.21 & 0.99 & 519.38 & -11.43 & 594.0 & 1.29 \\
\hline
\end{tabular}

Table 4. Comparison between the analytical and numerical methods of stagnation pressure

\begin{tabular}{cccccccc}
\hline \multirow{2}{*}{$\begin{array}{c}\text { Velocity } \\
\left(\mathbf{m s}^{-1}\right)\end{array}$} & \multirow{7}{c}{ Stagnation pressure (MPa) } \\
\cline { 2 - 8 } & \multirow{2}{*}{ Analytic } & \multicolumn{2}{c}{ Lagrangian } & \multicolumn{2}{c}{ Eulerian } & \multicolumn{2}{c}{ SPH } \\
\cline { 2 - 8 } & Value & Error (\%) & Value & Error (\%) & Value & Error (\%) \\
\hline 100 & 4.69 & 2.09 & -55.44 & 4.31 & -8.10 & 5.85 & 24.73 \\
\hline 200 & 18.76 & 3.21 & -82.89 & 16.56 & -11.73 & 17.80 & -5.12 \\
\hline 300 & 42.21 & 3.68 & -91.28 & 23.53 & -44.25 & 38.34 & -9.17 \\
\hline
\end{tabular}

Next, numerical modeling validation was carried out using bird dimensions according to the size of the sabot (bird container) on the bird impact test equipment owned by the National Institute of Aeronautics and Space (LAPAN). The dimensions of the bird are $74 \mathrm{~mm}$ in length and $129 \mathrm{~mm}$ in diameter. The experiment carried out by Wilbeck [13] was simulated, and then the results were compared between the numerical and experimental methods. The bird is impacted into the plate at a velocity of $200 \mathrm{~ms}^{-1}$ that the deformation stage is shown in Fig. 7. The results of the Hugoniot pressure value obtained from the center of the impact on the plate.

From the analysis, the Hugoniot pressure has a value of $361.93 \mathrm{MPa}$ and the stagnation pressure is $7.31 \mathrm{MPa}$ so that it gives a normalization value of 19.29 and 0.39 , respectively. The analytical values of Hugoniot pressure and stagnation pressure were calculated as $353.23 \mathrm{MPa}$ and 18.76 $\mathrm{MPa}$, which after normalizing gives 18.83 and 1 , respectively. The comparison of numerical, analytical, and experimental values of normalized pressure is shown in Fig. 8. The trend of the plot is consistent with experimental results where a sudden peak pressure value was observed at the initial shock and the pressure then stabilized with time. The duration of pressure decay was also in accordance with the experimental result.
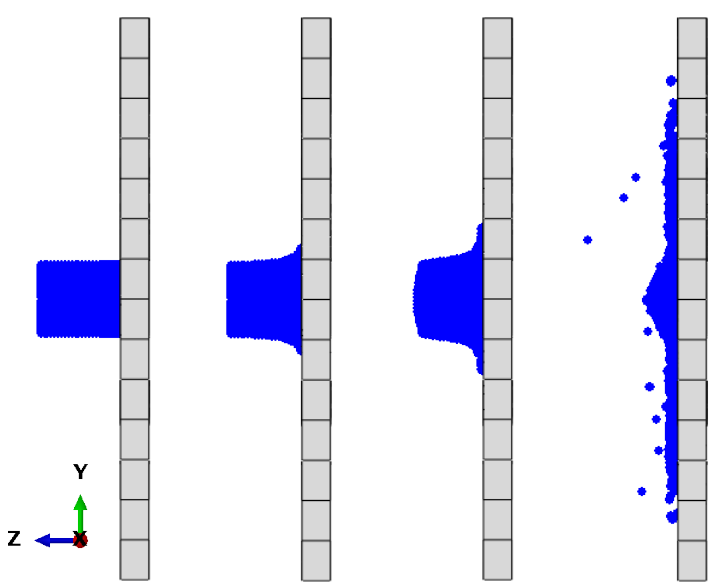

Figure 7. Deformation of a bird on impacting a steel plate at the time: (a) 0.018, (b) 0.098, (c) 0.195 , and (d) $0.888 \mathrm{~ms}$ 


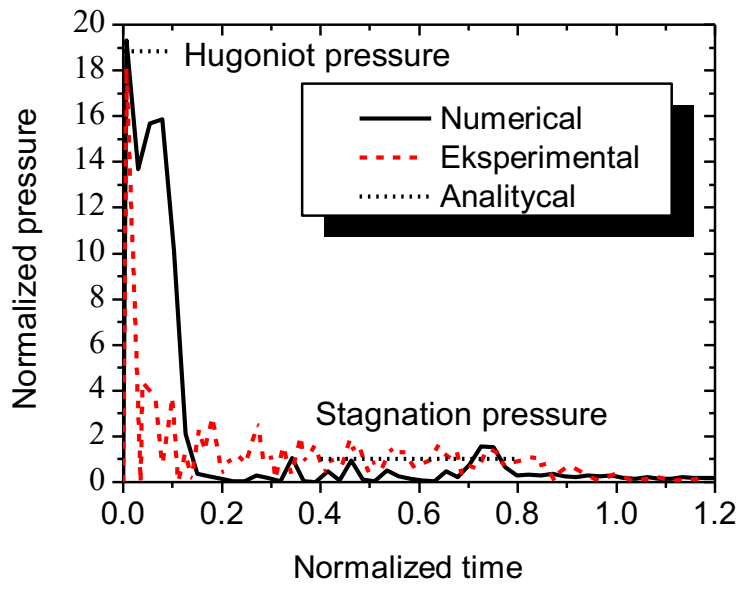

Figure 8. Comparison of pressure profile between the numerical, experimental, and analytical result

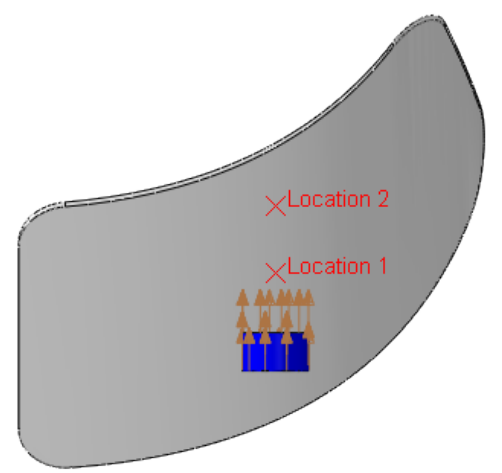

(a)

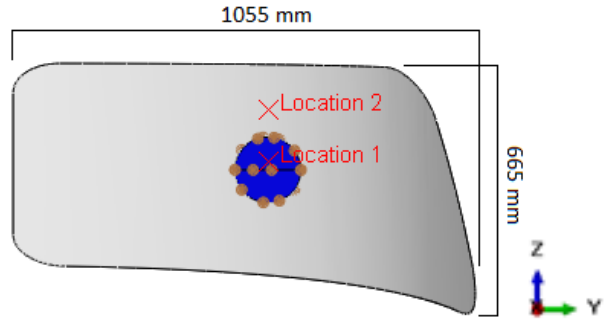

(c)

\subsubsection{Finite Element Model of Impact Problem}

The windshield was modeled with the solid element by using a Lagrangian grid as shown in Fig. 9. The windshield consists of 27686 elements. More refined elements distribution is adopted around the area of impact as most of the deformation takes place at this particular impact region as shown in Fig. 10. The bird was modeled as a right cylinder. The bird was modeled as a soft body with 6741 particles. The bird models that have been converted to particles are shown in Fig. 11.

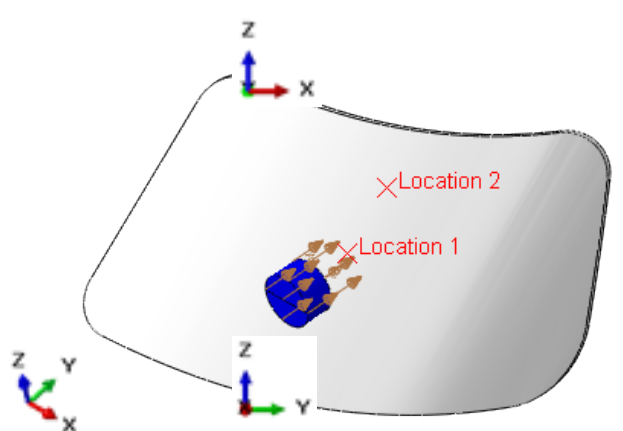

(b)

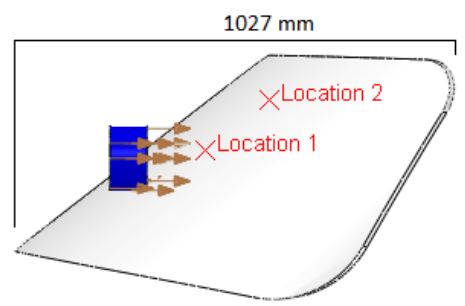

(d)

Figure 9. Finite element model of bird impact on the windshield: (a) upper, (b) isometric, (c) front, and (d) side view

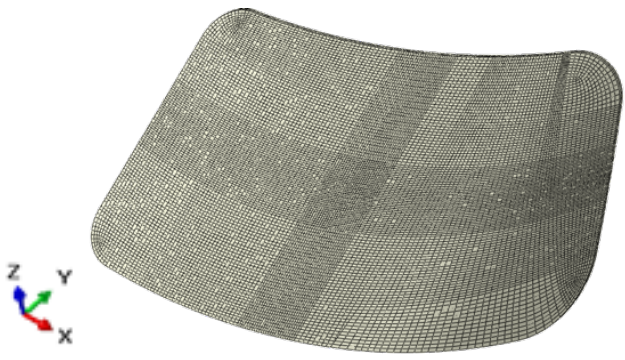

Figure 10. Refine mesh elements on the windshield

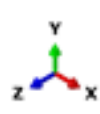

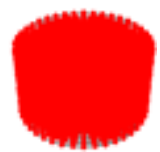

Figure 11. Bird model after being converted to particles

The elements in the mesh undergo severe distortion due to the high rate of deformation. These distorted elements must be removed from the mesh to run the program smoothly and to avoid a reduced time step problem. The deletion of distorted 
elements is carried out by using element deletion in Abaqus mesh. The contact between windshield and bird was defined by using the General contact interaction option of Abaqus because it represents the whole part of the model that has contact. In addition to this, this type is suitable for dynamic interactions between particles and Lagrangian elements. The edges of the windshield are fully constrained to provide fixed boundary conditions. Location 1 was marked on the windshield central line to record the values of displacement and force. Location 1 is selected which is the farthest point from the supporting structure (the edges of the windshield) and it faced directly with the pilot in carrying out his duties. In addition to this, location 2 was chosen to determine the response of the windshield when the bird has slide entirely.

\section{RESULTS AND DISCUSSION \\ 3.1 Simulation-based on CASR 23.775 Requirements}

In Fig. 12, the windshield with thicknesses of 5 and $6 \mathrm{~mm}$ are not strong enough to withstand the bird impact load. As a result, the uppermost of the windshield fails and is released from the support (fixed) so that it moves significantly in the negative direction on the z-axis accompanied by bending in the area around the impact. To avoid this, the thicknesses are increased to
7,8 , and $9 \mathrm{~mm}$. For thicknesses of 7 and 8 $\mathrm{mm}$, cracking only occurs at the uppermost of the windshield so that it does not cause significant movement. For a thickness of 9 $\mathrm{mm}$, no cracks or failures occur so that it is determined as the optimal thickness of the windshield in accordance with the regulation requirements. This thickness will also be used for simulations based on variations of impact velocity. The bird impact process is shown in Fig. 13 for a $9 \mathrm{~mm}$ windshield thickness based on CASR 23.775 requirements.

To investigate the windshield movement more accurately, Fig. 14 shows the displacement at the uppermost of the windshield marked by a red point in Fig. 12. For thicknesses of 5 and $6 \mathrm{~mm}$, the uppermost moves from its initial position, while for thicknesses of 7,8 , and $9 \mathrm{~mm}$, the uppermost remains and vibrates around its initial position.

Internal energy for the whole windshield model with variations in thickness is shown in Fig. 15. Increased thickness causes internal energy to decrease. This is because an increase in thickness causes deformation to decrease. For thicknesses of 5 and $6 \mathrm{~mm}$, internal energy after reaching the initial failure has a high value due to large deformation on the windshield (Fig. 12 (a) and (b)).

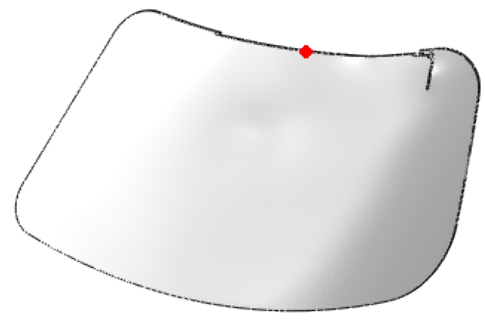

(a)

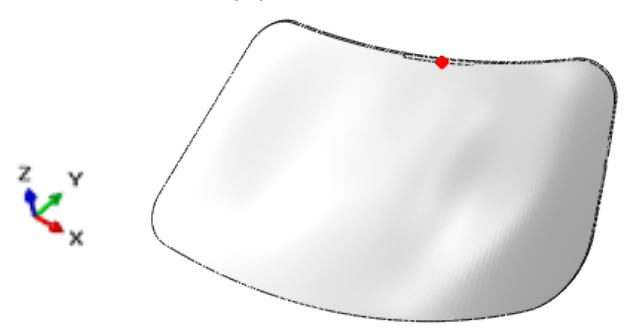

(d)

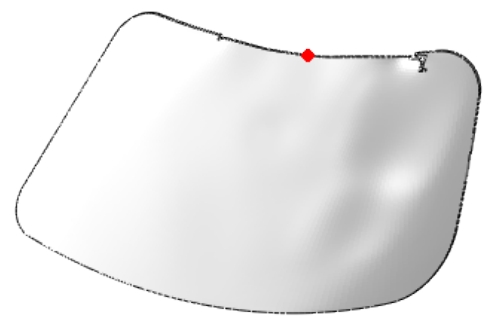

(b)

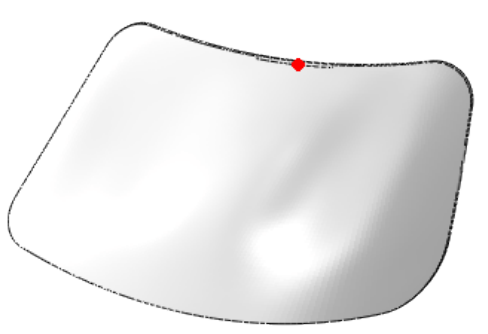

(c)

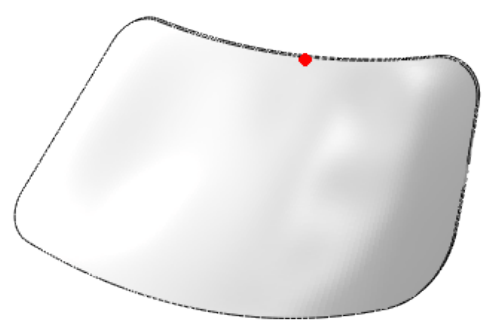

(e)

Figure 12. Deformation of the windshield based on regulatory requirements (impact velocity $62 \mathrm{~ms}^{-1}$, angle $0^{\circ}$, and bird mass $0.91 \mathrm{~kg}$ ) in thickness variations: (a) 5, (b) 6, (c) 7, (d) 8, and (e) $9 \mathrm{~mm}$. 


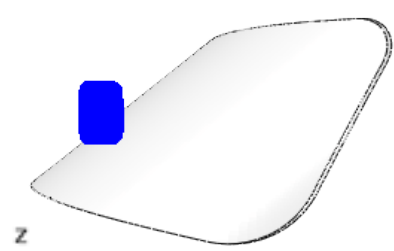

(a)

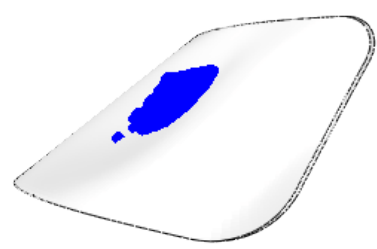

(b)

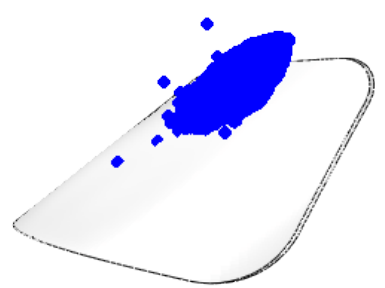

(c)

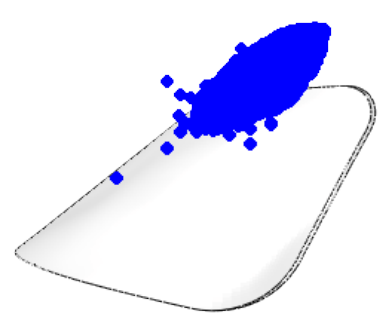

(d)

Figure 13. Different stages of deformation of the bird and windshield based on regulatory requirements with the windshield thickness of $9 \mathrm{~mm}$ for time interval: (a) 0, (b) 4, (c) 8, and (d) $10 \mathrm{~ms}$

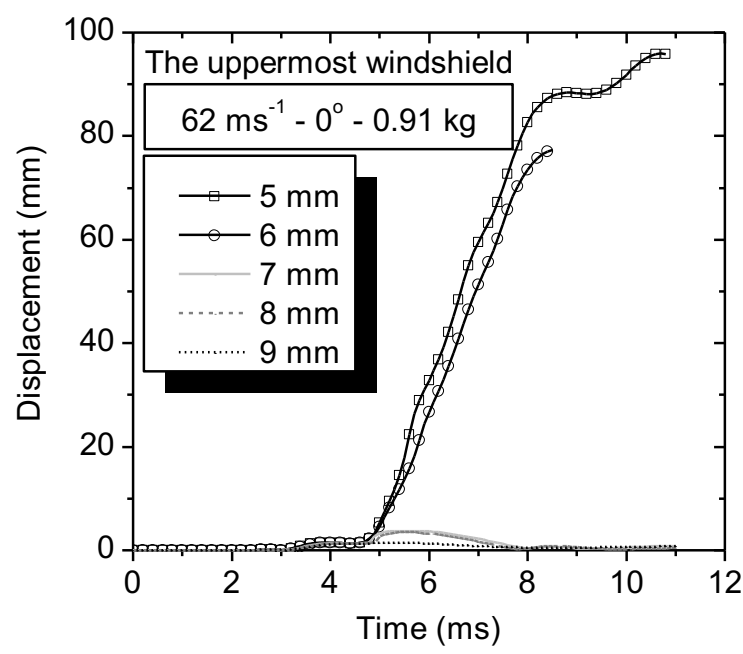

Figure 14. Displacement of the uppermost point of the windshield for different thicknesses

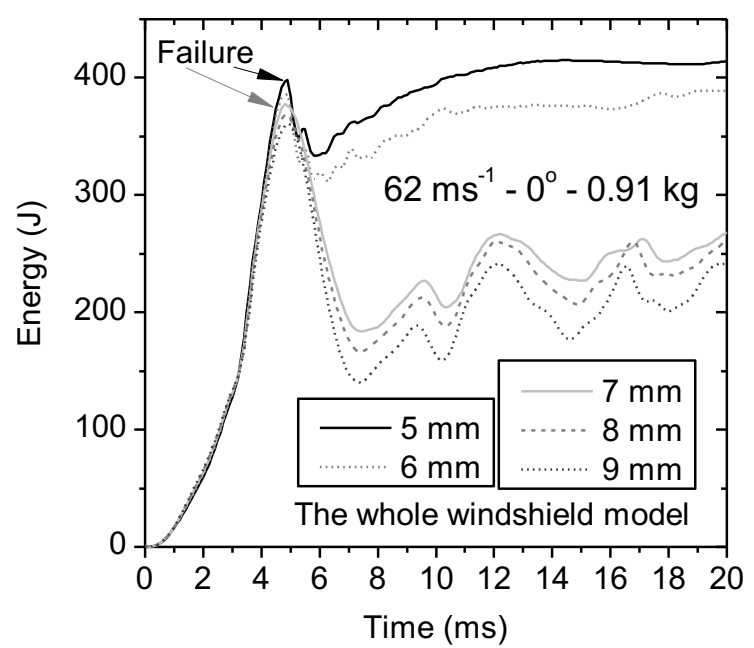

Figure 15. Internal energy absorbed by the windshield with different thicknesses

\subsection{Simulation of Impact Velocity Variations}

Simulations were carried out at the impact angle and bird mass as fixed parameters, namely $0^{\circ}$ and $0.91 \mathrm{~kg}$. Fixed parameters are considered according to CASR 23.775. The impact response of the windshield for various impact velocity was considered. It was noted that normal displacement at all gage locations increases with the increase of impact velocity. The displacement at location 1 (initial impact) is shown in Fig. 16. The time to reach maximum displacement at location 2 increases as they lie farther from point of impact (location 1). The displacement time plots for different impact velocity at locations 2 is shown in Fig. 17. An increase in impact velocity caused more deformation at the upper half of the windshield because more of the bird mass slide and transferred more energy to the upper end. However, for a velocity of $87.5 \mathrm{~ms}^{-1}$, the windshield experiences a significant displacement (exceeding the value of Location 1) due to the release of the uppermost from support (fixed).

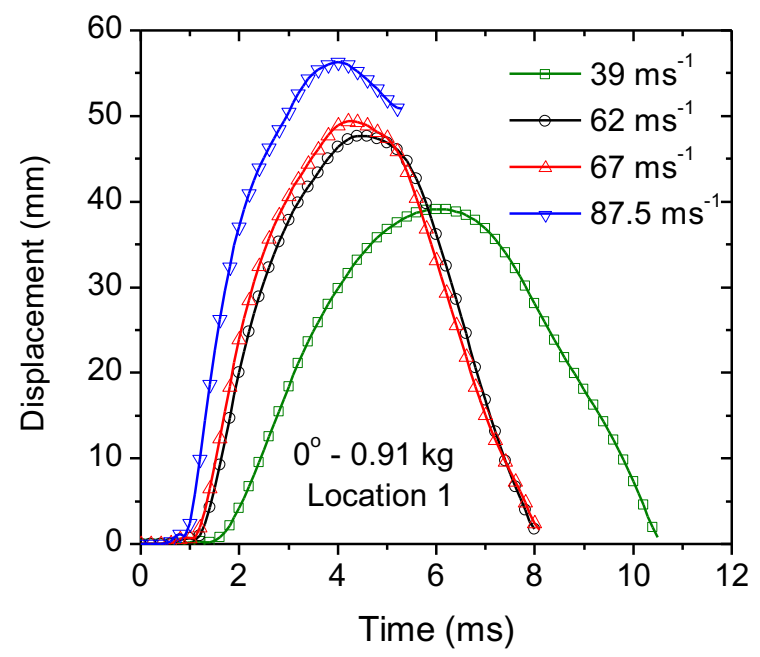

Figure 16. Displacement at Location 1 for impact velocity variations 


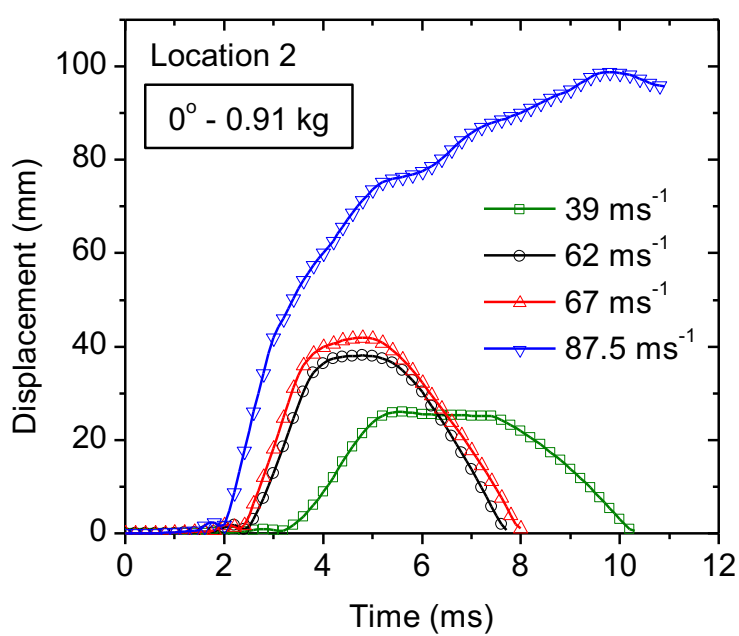

Figure 17. Displacement at Location 2 for impact velocity variations

The impact force also increases with the change of impact velocity as shown in Fig. 18. For velocity of $39 \mathrm{~ms}^{-1}$, the maximum impact force of $16.72 \mathrm{~N}$ is recorded at $4 \mathrm{~ms}$ which rises to $102.77 \mathrm{~N}$ at $1 \mathrm{~ms}$ for a velocity of $87.5 \mathrm{~ms}^{-1}$. An increase of 6 times in maximum impact force was observed due to a change in impact velocity from $39 \mathrm{~ms}^{-1}$ to $87.5 \mathrm{~ms}^{-1}$.

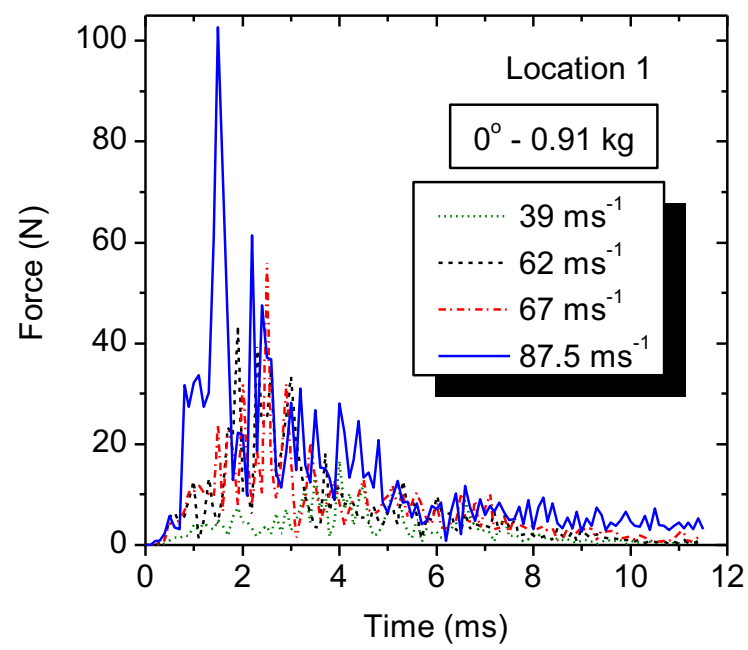

Figure 18. Impact force history for different impact velocity

When the impact velocity is increased, the stresses increase due to a higher impact force and the windshield tends to deform plastically. With further increase in impact velocity, the windshield shield reaches its elastic limit and suffers from permanent deformation leading to its complete failure. The stress distributions on the windshield for different impact velocity are shown in Fig. 19. At all impact velocity, the stress that occurs at the uppermost of the windshield has exceeded the yield strength of the material (68 MPa) even almost equals to the maximum stress material (78 $\mathrm{MPa})$ with values of $77.46,77.95$, and $77.98 \mathrm{MPa}$. For each impact velocity, there is a stress concentration at the upper- and lowermost of the windshield which is indicated to be the initial location of the failure. However, the stress concentration at the uppermost is more dominant than the lowermost because the geometry of the windshield has a slope so that the bird continuously moves upward (the vector between positive $y$ and $z$ axes in Fig. 19) during the impact.

The plastic strain area of the windshield extends as the impact velocity increases as shown in Fig. 20. The plastic strain occurs at the uppermost of the windshield at all impact velocity indicating that the area experiences stress exceeding the yield strength of the material. Windshield begins to crack (local failure) at the uppermost at an impact velocity of $67 \mathrm{~ms}^{-1}$ which is considered as a critical factor. For the impact velocity exceeds $67 \mathrm{~ms}^{-1}$, there will be a global failure that allows birds to penetrate the windshield. The failure is caused by the strain in which the value equals or exceeds the maximum strain failure criterion of the material, namely 0.067 .

When the impact, contact between the bird and windshield causes the windshield to receive the force so that deformation occurs. The deformation indicates the transfer of energy from birds to the windshield. Fig. 21 shows the kinetic and internal energy in each model for the velocity of $62 \mathrm{~ms}^{-1}$, angle of $0^{\circ}$, and bird mass of $0.91 \mathrm{~kg}$ in accordance with the regulatory parameters. Overall, the kinetic and internal energy trends for each model in the parameter variations almost equal (only the maximum value for each energy in each model difference) as shown in Table $\mathbf{5}$. 


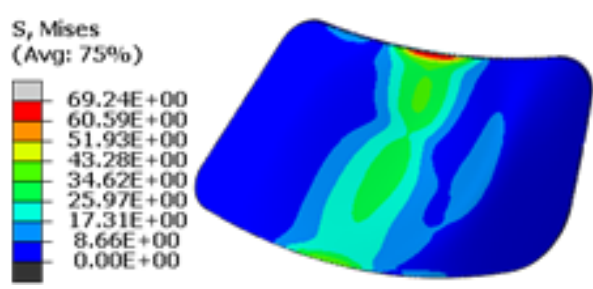

(a)

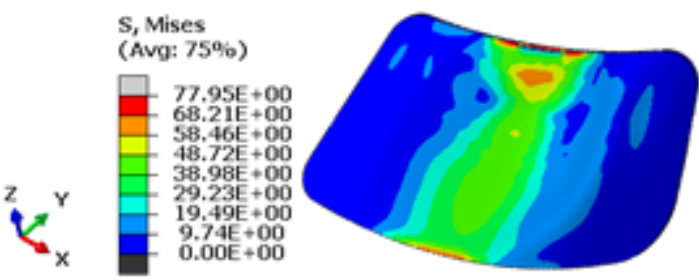

(c)

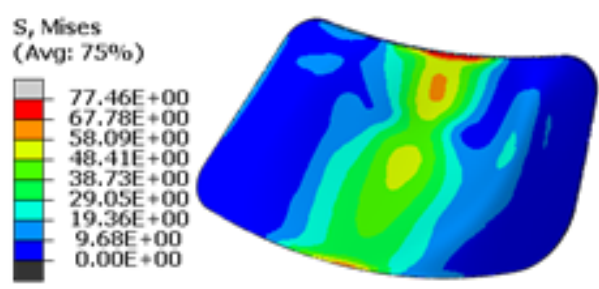

(b)

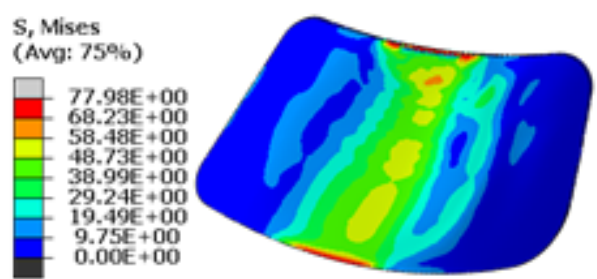

(d)

Figure 19. Stress distribution on the windshield for impact velocity variations: (a) 39; (b) 62; (c) 67; and (d) $87.5 \mathrm{~ms}^{-1}$
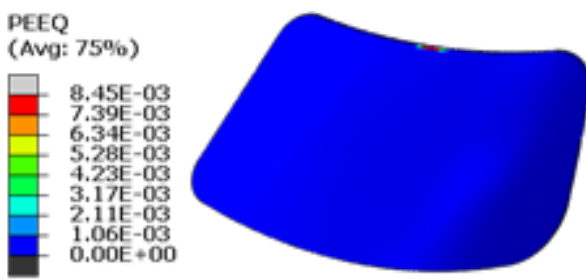

(a)
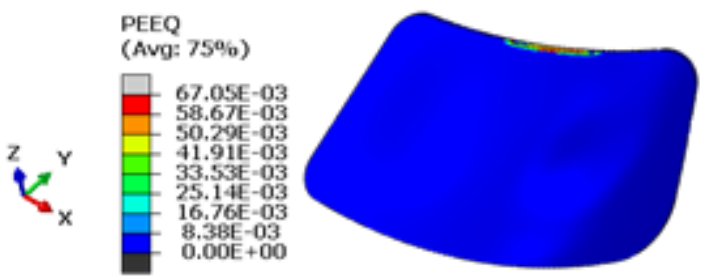

(c)

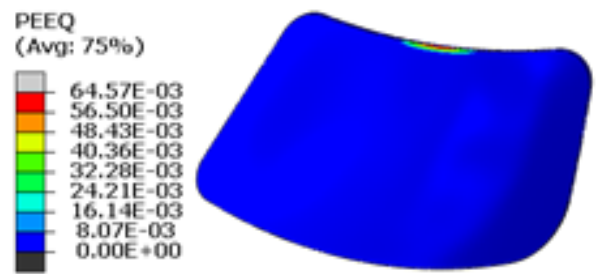

(b)

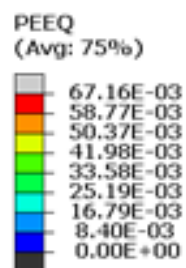

$0.00 E+00$

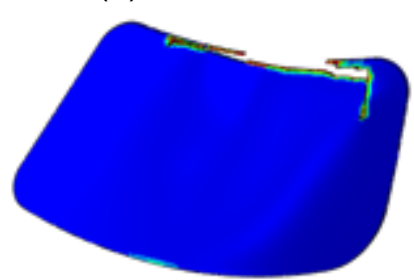

(d)

Figure 20. Plastic area on the windshield for impact velocity variations: (a) 39; (b) 62; (c) 67; and (d) $87.5 \mathrm{~ms}^{-1}$

Based on Fig. 21, at the initial of the impact, there was a decrease in the kinetic energy of the bird, an increase in the windshield kinetic energy, and an increase in internal energy for each model. The decrease in the kinetic energy of birds is caused by the impact which causes a decrease in velocity of the bird. The increase in windshield kinetic energy is caused by the transfer of the kinetic energy of the bird to the windshield so that occurs the deformation velocity. The increase in internal energy for both models is caused by elastic deformation.

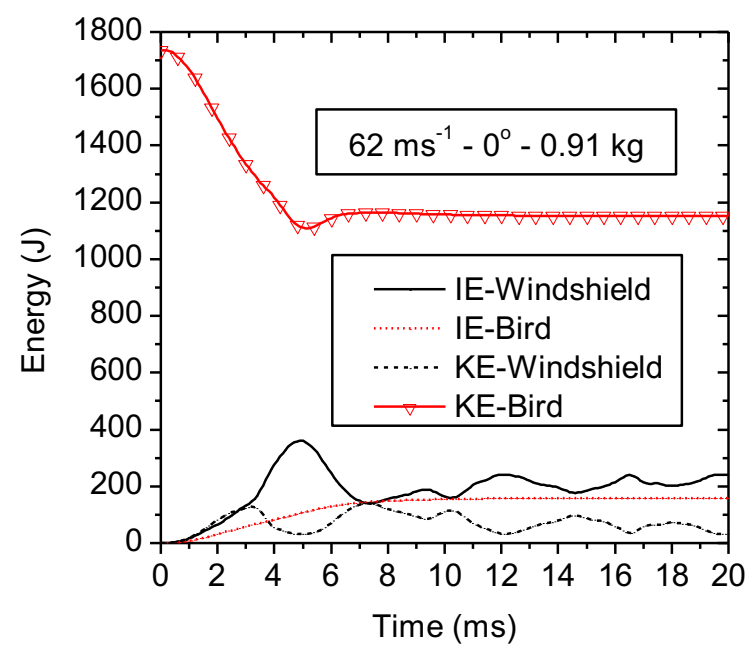

Figure 21. Kinetic and internal energy each model 
In Fig. 21, the kinetic energy of $1736.48 \mathrm{~J}$ is absorbed by the windshield and drops to a constant value (around 1154.98 $\mathrm{J})$ at $11.2 \mathrm{~ms}$ when the bird leaves the windshield with a decrease in velocity. At the same time, the bird internal energy begins to experience a stable condition because it no longer experiences energy absorption. The internal energy of the windshield is not stable until the end of the simulation because it is still experiencing deformation. With increasing time, the kinetic energy of the windshield decreases because the deformation velocity of the windshield also decreases.

Table 5. Kinetic and internal energy maximum of the bird and the windshield for impact velocity variations

\begin{tabular}{ccc}
\hline $\begin{array}{c}\text { Velocity } \\
\left(\mathbf{m s}^{-1}\right)\end{array}$ & $\begin{array}{c}\text { The kinetic } \\
\text { energy of } \\
\text { the bird }(\mathbf{J})\end{array}$ & $\begin{array}{c}\text { The internal } \\
\text { energy of the } \\
\text { windshield }(\mathbf{J})\end{array}$ \\
\hline 39 & 687.09 & 125.98 \\
\hline 62 & 1736.48 & 360.76 \\
\hline 67 & 2027.85 & 434.74 \\
\hline 87.5 & 3458.62 & 826.84 \\
\hline
\end{tabular}

Fig. 22 shows that an increase in impact velocity causes the windshield internal energy to increase. Failures occur at a velocity of 67 and $87.5 \mathrm{~ms}^{-1}$ at 5.3 and 3.2 ms (marked "Failure") with energy absorption of 403.27 and $567.27 \mathrm{~J}$, respectively. At a velocity of $87.5 \mathrm{~ms}^{-1}$, the energy trend after reaching the initial failure tends to increase due to large deformations in the windshield. To give a simple understanding of the curve for the velocity of $87.5 \mathrm{~ms}^{-1}$ (blue line with a triangle symbol), Fig. 23 shows the bird impact process.

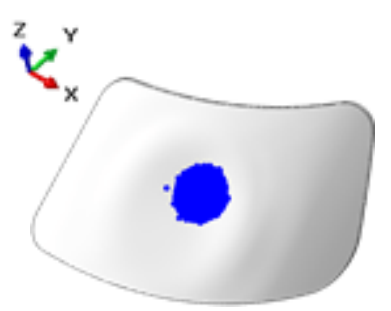

(a)

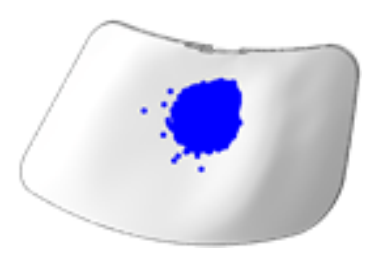

(b)

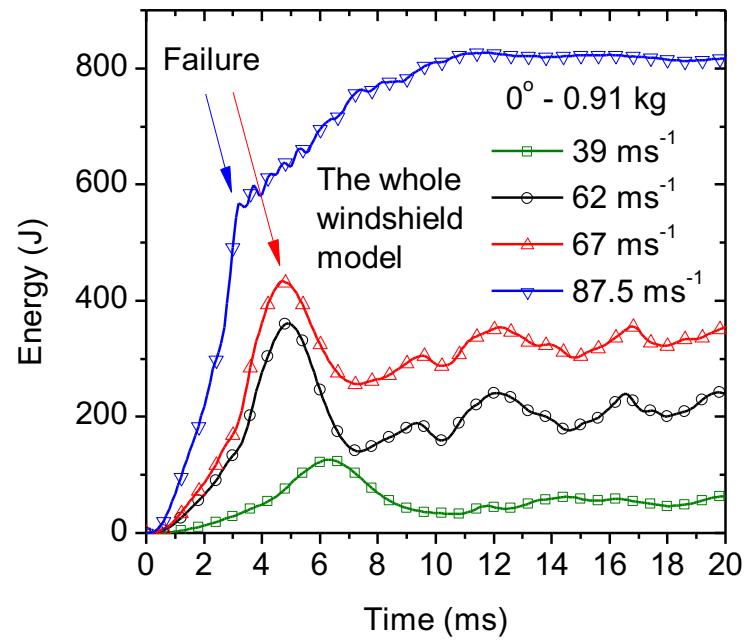

Figure 22. Internal energy absorbed by the windshield with different impact velocity

Table 6 shows the change in kinetic energy before and after the impact for variations in velocity with the impact angle of $0^{\circ}$ and the bird mass of $0.91 \mathrm{~kg}$. The largest percentage change in kinetic energy occurred at a velocity of $87.5 \mathrm{~ms}^{-1}$, namely $37.41 \%$, followed by the velocity of $67 \mathrm{~ms}^{-1}$ (35.65\%), $62 \mathrm{~ms}^{-1}(33.49 \%)$, and $39 \mathrm{~ms}^{-1}$ $(31.67 \%)$. In the velocity of $87.5 \mathrm{~ms}^{-1}$ shows that the largest decrease in bird velocity and mass occurred.

Table 6. Changes in the kinetic energy of the bird before and after impact

\begin{tabular}{|c|c|c|c|}
\hline \multirow{2}{*}{$\begin{array}{l}\text { Velocity } \\
\left(\mathrm{ms}^{-1}\right)\end{array}$} & \multicolumn{2}{|c|}{ Kinetic energy $(\mathrm{J})$} & \multirow{2}{*}{$\begin{array}{c}\text { Kinetic } \\
\text { energy } \\
\text { difference } \\
(\%) \\
\end{array}$} \\
\hline & $\begin{array}{l}\text { Before } \\
\text { impact }\end{array}$ & $\begin{array}{c}\text { After } \\
\text { impact }\end{array}$ & \\
\hline 39 & 687.09 & 469.47 & 31.67 \\
\hline 62 & 1736.48 & 1154.98 & 33.49 \\
\hline 67 & 2027.85 & 1304.91 & 35.65 \\
\hline 87.5 & 3458.62 & 2164.87 & 37.41 \\
\hline
\end{tabular}

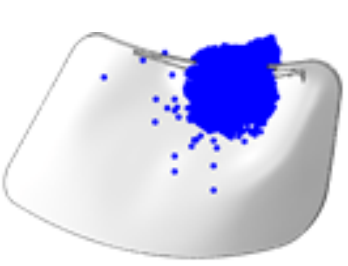

(c)

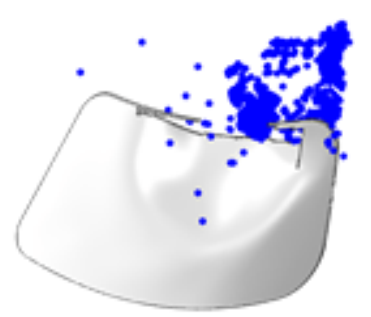

(d)

Figure 23. Different stages of deformation of the bird and windshield for impact velocity based on time intervals: (a) 0, (b) 4, (c) 8, and (d) $10 \mathrm{~ms}$

To determine the level of resilience of the windshield, a simulation is carried out by increasing the impact velocity. The meaning of resilience is to the extent that the 
windshield begins to fail in the initial impact area (middle of the windshield). The simulation is carried out by iterating the increase of impact velocity (impact angle of $0^{\circ}$ and bird mass of $0.91 \mathrm{~kg}$ ). As a result, the windshield began to fail in the middle when the impact velocity was $170 \mathrm{~ms}^{-1}$. The windshield visualization after the impact is shown in Fig. 24.
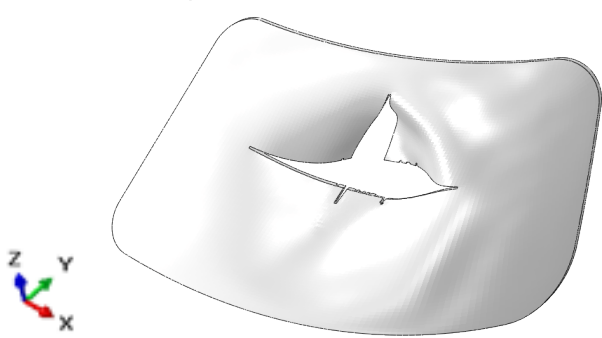

Figure 24. Failure on the windshield in the initial of the impact on the velocity of $170 \mathrm{~ms}^{-1}$

\section{CONCLUSIONS}

The behavior of the windshield against bird impact was successfully simulated and the effect of various impact velocity on its dynamic response was studied. Impact velocity that causes the dynamic response of the windshield in the form of elastic and plastic deformation, as well as failure in the local area, is $67 \mathrm{~ms}^{-1}$. This is indicated by the occurrence of failures in the uppermost area of the windshield. However, the impact velocity that causes the windshield's most dynamic response is $87.5 \mathrm{~ms}^{-1}$. This is indicated by the absorption of windshield energy that is higher than other impact velocities. In addition, the percentage change in kinetic energy before and after the impact is also the largest, namely $37.41 \%$. The uppermost of the windshield (fixed boundary condition) is the weakest part due to the stress concentration (high stress) which is linearly related to the maximum strain failure criteria of the material.

\section{ACKNOWLEDGMENTS}

This study is supported by the National Institute of Aeronautics and Space (LAPAN).

\section{REFERENCES}

[1] Wahyudi, M., 2010, N219, Pesawat untuk Landasan Pendek, https://money.kompas.com/read/2010/ 12/31/04573584/n219.pesawat.untuk.I andasan.pendek.?page=all, accessed I 2 March 2019.

[2] Republic of Indonesia Ministry of Transportation, 2001, Civil Aviation Safety Regulation Part 23 Amendment 1, Airworthiness Standards: Normal, Utility, Acrobatic, and Commuter Category Airplanes.

[3] Federal Aviation Administration, 2019, FAA Wildlife Strike Database, https://wildlife.faa.gov/home, accessed 4 March 2019.

[4] Heimbs, S., 2011, Computational Methods for Bird Strike Simulations: A review, Computers and Structures, No. 23, Vol. 89, 2093-2112.

[5] Heimbs, S., 2011, Bird Strike Simulations on Composite Aircraft Structures, European Aeronautic Defence and Space Company, Innovation Works, 81663 Munich, Germany.

[6] Hedayati, R., Mojtaba, S., 2016, Bird Strike An Experimental, Theoretical, and Numerical Investigation, Woodhead Publishing, UK.

[7] Zhu, S., Tong, M., Wang, Y., 2009, Experiment and Numerical Simulation of a Full-Scale Aircraft Windshield Subjected to Bird Impact, Proceedings of the $50^{\text {th }}$ AIAA/ASME/ASCE/AHS/ASC

Structures, Structural Dynamics, and Materials Conference, Palm Springs, California, USA.

[8] Xinjun, W., Zhenzhou, F., Fusheng, W., Zhufeng, Y., 2007, Dynamic Response Analysis of Bird Strike on Aircraft Windshield Based on Damage-modified Nonlinear Viscoelastic Constitutive Relation, Chinese Journal of Aeronautics, No. 6, Vol. 20, 511-517.

[9] Wang, F.S., Yue, Z.F., 2010, Numerical Simulation of Damage and Failure in Aircraft Windshield Structure Against Bird Strike, Material and Design, No. 2, Vol. 31, 687-695.

[10] Dar, U.A., Zhang, W., Xu, Y., 2013, FE Analysis of Dynamic Response of Aircraft Windshield against Bird Impact, International Journal of Aerospace Engineering, China. 
[11] Yuniarti, E., Sitompul, S.A., 2019, Pengaruh Model Burung Silinder dan Silinder Dengan Kedua Ujung Setengah Bola Dengan Pemodelan Elemen Hingga Kasus Tabrak Burung, Jurnal Teknologi Dirgantara, No. 1, Vol. 17, 41-56.

[12] Dassault Systemes, 2011, A Strategy for Bird Strike Simulations using Abaqus-Explicit, SIMULIA.

[13] Wilbeck, J. S., 1978, Impact Behavior of Low Strength Projectiles, Technical Reports AFML-TR-77-134, Air Force Materials Laboratory, Air Force Wright Aeronautical Laboratories, Air Force Systems Command, Wright-Patterson Air Force Base, Ohio. 